\title{
DNA phylogeny of Ryukyus Leucothoidae (Crustacea: Amphipoda)
}

\author{
Kristine N. White ${ }^{1,2}$, James D. Reimer ${ }^{1}$ \\ ${ }^{1}$ Rising Star Program, Trans-disciplinary Organization for Subtropical Island Studies (TRO-SIS), University of \\ the Ryukyus, 1 Senbaru, Nishihara, Okinawa, Japan 903-0213 \\ ${ }^{2}$ E-mail: white.kristinen@gmail.com
}

Keywords: 18S rDNA, anamixid clade, host specificity, Japan, leucothoid clade

\begin{abstract}
Commensal leucothoid amphipods collected from sponges, ascidians, and coral rubble from the Ryukyu Archipelago, Japan, were investigated using nuclear $18 \mathrm{~S}$ ribosomal DNA sequences. Analysis of sequences from 21 species in three genera supported the current morphological species designations and the separation of the family into two clades. Additionally, a possible new generic-level clade was identified and the separation of the genera Anamixis and Paranamixis was not supported. Our results demonstrate that host specificity appears to evolve rapidly in sibling species in this family.
\end{abstract}

\section{Contents}

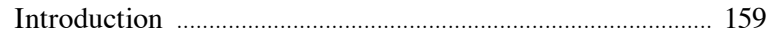

Material and methods ............................................................. 160

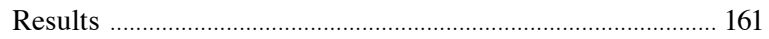

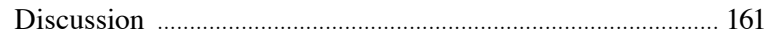

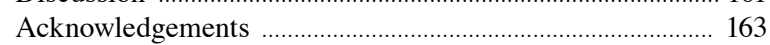

References .......................................................................... 164

\section{Introduction}

Leucothoid amphipods are commensal peracarid crustaceans, typically associated with sessile invertebrate hosts such as sponges, ascidians, or bivalve mollusks. They are also found in crevices in coral rubble, presumably associated with filter feeding organisms (e.g. sponges) within the rubble. Currently, there are 163 species of Leucothoidae described from coral reefs to the deep sea (White, 2011a; White and Reimer, 2012a, $\mathrm{b}, \mathrm{c})$, but it is likely many more undiscovered and undescribed species exist given the cryptic habitats and small sizes of many species in this family (Thomas and Klebba, 2006; Thomas, 2008; White, 2010; Thomas and Krapp-Schickel, 2011).

In 2012, White and Reimer described 24 new species of Leucothoidae with their host associations from the Ryukyu Archipelago in southern Japan (2012a, b, c). Prior to this research only seven species had been reported from mainland Japan, with no reports from the Ryukyu Archipelago, and only one species had associated host information available (discussed in White and Reimer, 2012a).

Despite the progress made in species descriptions of Leucothoidae from some regions of the world, little research has been conducted on their molecular phylogeny, with only two reports in the literature. As of March 3, 2012, GenBank lists approximately 10,000 sequences for Amphipoda, with 921 of these being 18S ribosomal DNA (18S rDNA) sequences (Benson et al., 2005). Molecular sequence data are scarce for Leucothoidae, comprising only 94 of the total amphipod sequences. Of these 94 sequences, 30 are 18S rDNA sequences for 10 species in two genera from Florida, Belize, and Indonesia (Anamixis and Leucothoe) (White, 2011b). The remaining 64 are partial COI sequences for three species (Leucothoe ashleyae Thomas and Klebba, 2006; Leucothoe kensleyi Thomas and Klebba, 2006, and one sequence for Anamixis vanga Thomas, 1997) from Florida and Belize (Richards et al., 2007; White, 2011b).

White (2011b) utilized specimens from Florida, Belize, and Indonesia, and documented the utility of 18S rDNA as a species-level molecular marker for the Leucothoidae, while supporting the separation of the family into two large clades. The 'leucothoid' clade was shown to contain the genera Leucothoe Leach, 1814 and Paraleucothoe Stebbing, 1899, while the 'anamixid clade' contained Anamixis Stebbing, 1897, Nepanamixis Thomas, 1997, and Paranamixis Schellenberg, 1938. The genera Anamixis and Paranamixis are currently distinguished from each other based on the presence of gnathopod 1 and a cleft maxilliped inner plate in Anamixis species. However, in addition to the molecular results of White (2011b), recent morphological analyses 
also do not support the separation of these two genera based on these characters (White, 2010). Thus, it is clear further phylogenetic analyses are needed to clarify our evolutionary understanding of this unique amphipod family.

In this study, we obtained and phylogenetically analyzed sequences from 21 species of Leucothoidae from the Ryukyu Archipelago. We examine the phylogenetic relationships within the Leucothoidae, and also discuss the potential evolutionary significance of host relationships.

\section{Material and methods}

Leucothoid amphipods for this study were collected from marine sponges, ascidians, and coral rubble from throughout the Ryukyu Archipelago, Japan, as reported in White and Reimer (2012a, b, c). These collections included detailed host association and location data (GPS coordinates, depth etc.), as such associations were previously unknown for most of the described species in the Leucothoidae. Specimens, station data, and GenBank accession numbers are listed in Table S1.

Genomic DNA was extracted from the urosomes of representative individual ethanol-preserved animals after morphological examination. In total, DNA from one to six specimens each of 24 morphologically determined Leucothoidae species was extracted. Voucher specimens are deposited in The University of the Ryukyus Museum (Fujukan), with the prefix RUMF for museum numbers. Extractions were performed using a guanidine extraction protocol (Sinniger et al., 2010). Partial 18S rDNA sequences were amplified (697-851 base pairs including the V4 hypervariable region) using polymerase chain reaction (PCR) (Saiki et $a l .$, 1988). PCR protocols were used following Spears et al. (2005). The following peracarid-specific primers were used for 18S rDNA: 329 (5'-TAATGATCCTTCCGCAGGTT-3') and Hi- (5'-GTGCATGGCCGTTC TTAG-TTG-3') (Spears et al., 2005). PCR products were purified using shrimp alkaline phosphatase (SAP) and gel purified with a Qiagen gel extraction kit if non-specific PCR products were apparent after gel electrophoresis.

Sequencing was done by Fasmac (Yokohama, Japan). Sequences were edited, combined, and initially aligned in Bioedit 7.0.5.3 (Hall, 1999) and the alignments were further edited by eye using SeaView 4.3.3 (Guoy et al., 2010) and Se-Al v.2.01 (Rambaut, 2002).
Three different alignments were constructed in order to examine the influence of hypervariable regions on resulting phylogenetic trees, as some studies suggest deleting these regions (e.g. Kim and Abele, 1990; Spears et al., 1992; Carmean et al., 1992; Pashley et al., 1993; Campbell et al., 1994; Friedrich and Tautz, 1995; Kim et al., 1996; Chalwatzis et al., 1996; Giribet et al., 1996; Friedrich and Tautz, 1997; Spears and Abele, 2000) while others propose retaining them (Crease and Taylor, 1998; Hwang et al., 2000; White, 2011b). The first alignment contained all variable regions including the V4 hypervariable region ('long' alignment). The second alignment retained all variable regions except the V4 hypervariable region ('medium'). The final alignment retained only conserved regions ('short'). All three generated alignments contained sequences for 40 taxa (including two outgroup taxa). Representatives of the amphipod family Liljeborgiidae Stebbing, 1899 were chosen as outgroup taxa based on the loss of molar structure and rudimentary charpochelation of gnathopod 1 (more primitive than the fully carpochelate gnathopod 1 in Leucothoidae) in the Liljeborgiidae (Barnard, 1974). The long alignment dataset contained 1205 sites, the medium alignment 751 sites, and the short alignment 426 sites. All three alignments are available from the corresponding author and at the homepage http://web.me.com/miseryukyu/.

All three alignments resulted in trees with identical topologies based on preliminary maximum likelihood (ML) and neighbor-joining (NJ) analyses, with the short and medium trees showing generally lower bootstrap support values at most nodes. For these reasons, we therefore utilized the long alignment for all subsequent analyses. Uncorrected measures of percentsequence divergence were obtained using Mesquite V2.74 (Maddison and Maddison, 2011). The levels of divergence used were $0-0.023$ between different populations of a species, 0.090-0.295 between species within a genus, 0.260-0.349 between different genera within the Leucothoidae, and greater than 0.306 between leucothoid genera and the outgroup, Liljeborgiidae (after White, 2011b).

Twenty one ingroup taxa were included in the analyses due to lack of specimens or difficulty of obtaining molecular data from the other four species collected in the Ryukyus. PhyML (Guindon and Gascuel, 2003) was used for ML analyses using an input tree generated by BIONJ (Neighbor Joining) with the Generalized Time Reversible (GTR) model, incorporating invariable sites and a discrete gamma distribution with eight 
substitution rate categories. Base frequencies were estimated from the dataset. Support for the maximum likelihood tree was measured using the bootstrap method with 1,000 replicates in PhyML.

$\mathrm{NJ}$ analysis was accomplished in SeaView 4.3.3 using Jukes Cantor (JC) distance methods. Support was measured using the bootstrap method with 1,000 replicates in SeaView 4.3.3.

Bayesian phylogenetic inference analysis (B) was accomplished using MrBayes 3.1.2 (Ronquist and Huelsenbeck, 2003) under GTR $+\mathrm{I}+\Gamma$. One cold and three heated Markov chains Monte Carlo (MCMC) with default-chain temperatures were run for 5 million generations, sampling log-likelihoods. Trees at 1000generation intervals were saved (5000 InLs and trees saved during MCMC). The likelihood plot suggested that MCMC reached a stationary phase after the first $1,000,000$ generations, and thus the remaining 4,000 trees were used to obtain clade probabilities and branch-length estimates.

\section{Results}

Maximum likelihood (ML) analysis of partial 18S rDNA sequences of all available Ryukyus species' sequences resulted in a tree with generally high bootstrap support values for most nodes. Neighbor Joining (NJ) analysis resulted in an identical distance tree with high bootstrap support values. Bayesian analysis (B) resulted in a phylogenetic tree identical to the ML tree with high posterior probabilities.

The resulting 18S rDNA tree depicted two major clades (Fig. 1), one composed of Anamixis and Paranamixis species (ML $=100 \%, \mathrm{NJ}=100 \%, \mathrm{~B}=1.00)$ and the other containing Leucothoe species $(\mathrm{ML}=$ $92 \%, \mathrm{NJ}=72 \%, \mathrm{~B}=1.00$ ). The anamixid clade did not have prominent subclades, grouping Anamixis sentan White and Reimer, 2012c and Paranamixis thomasi White and Reimer, 2012a into one clade. The 18S rDNA sequence data also supported the connection of leucomorphs and anamorphs of $P$. thomasi $(\mathrm{ML}=69 \%, \mathrm{NJ}$ $=99 \%, \mathrm{~B}=1.00)$. The connection of anamorphs and leucomorphs was not possible for A. sentan as only leucomorphs were sequenced. The leucothoid clade depicted two distinct subclades within the genus Leucothoe. A new generic-level subclade grouped morphologically similar species (Leucothoe toribe White and Reimer, 2012b, Leucothoe obuchii White and Reimer, 2012a, Leucothoe enko White and Reimer, 2012c, and Leucothoe kebukai White and Reimer, 2012c) together $(\mathrm{ML}=100 \%, \mathrm{NJ}=100 \%, \mathrm{~B}=1.00)$. Within the larger Leucothoe subclade (ML $=86 \%$, NJ $=98 \%, \mathrm{~B}=1.00$ ), multiple specimens of each species formed subclades.

Four morphologically similar species (Leucothoe vulgaris White and Reimer, 2012a, Leucothoe amamiensis White and Reimer, 2012a, Leucothoe akuma White and Reimer, 2012c, and Leucothoe akaisen White and Reimer, 2012c) formed a subclade separate from all other Leucothoe species within the leucothoid subclade $(\mathrm{ML}=92 \%, \mathrm{NJ}=100 \%, \mathrm{~B}=1.00)$. Five specimens of Leucothoe elegans White and Reimer, 2012a formed a subclade with Leucothoe hashi White and Reimer, 2012b, Leucothoe zanpa White and Reimer, $2012 \mathrm{~b}$ and Leucothoe lecroyae White and Reimer, $2012 \mathrm{~b}$, depicting minor population differences between Okinawa-jima, Amami-oshima, and Hiroshima populations of L. elegans $(\mathrm{ML}=90 \%, \mathrm{NJ}=67 \%, \mathrm{~B}=$ 1.00). The final subclade in the Leucothoe subclade was comprised of morphologically similar species (Leucothoe trulla White and Reimer, 2012a, Leucothoe bise White and Reimer, 2012b, Leucothoe nurunuru White and Reimer, 2012b, Leucothoe daisukei White and Reimer, 2012b, and Leucothoe akaoni White and Reimer, 2012b) (ML $=68 \%, \mathrm{NJ}=<50 \%, \mathrm{~B}$ $=1.00$ ).

\section{Discussion}

After many unsuccessful attempts by the first author at amplifying and sequencing multiple molecular markers (cytochrome oxidase subunit 1, 12S ribosomal DNA, 16S ribosomal DNA) for Leucothoidae, this study focused on nuclear $18 \mathrm{~S}$ rDNA. Several studies have found that the hypervariable regions of $18 \mathrm{~S}$ are taxon specific and useful as a species-level marker (Hwang et al., 2000; White, 2011b) and several amphipod molecular phylogenies have been based at least partially on 18S rDNA, including gammaridean Lake Baikal amphipods (Sherbakov et al., 1999; Macdonald et al., 2005), subterranean gammaridean amphipods (Englisch and Koenemann, 2001), Gammarus species (Hou et al., 2007), and caprellid and corophioid taxa (Ito et al., 2008).

While all three alignments in this study grouped the taxa into the same clades, the long alignment, containing the V4 hypervariable region, showed the strongest bootstrap support for species, suggesting that full length 18S rDNA sequences are an excellent marker at the species-level and potentially useful for 


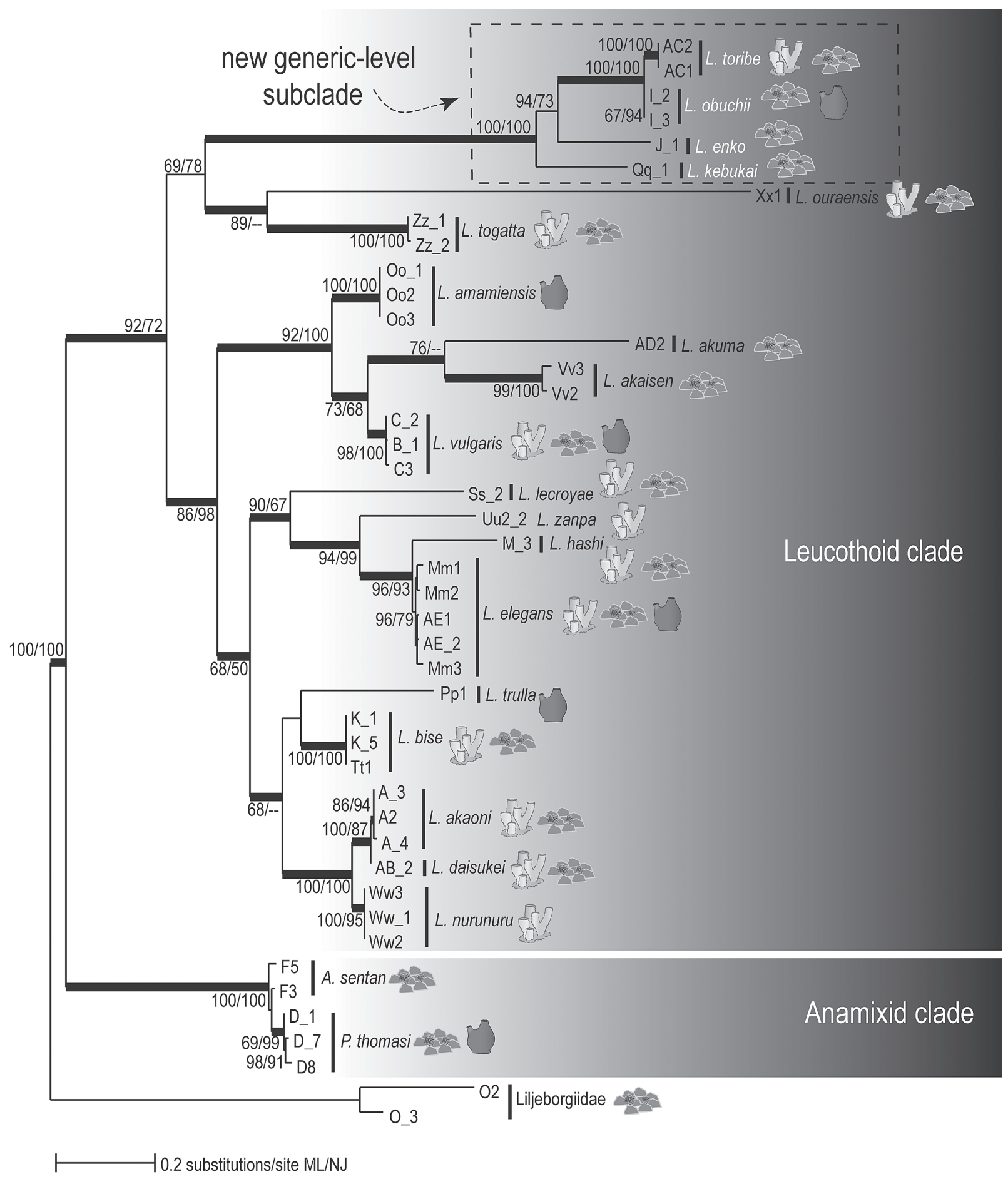

Fig. 1. Maximum likelihood (ML) phylogenetic tree of 'long' partial 18S ribosomal DNA gene sequences from replicates of 21 Leucothoid taxa collected from depths of 1-33 meters, rooted with an outgroup of two Liljeborgiid species. Numbers at branches represent $\mathrm{ML} /$ Neighbor joining (NJ) bootstrap values. Thick lines represent Bayesian posterior probabilities $>0.95$. 
population studies. Removing the variable regions in the shorter 18S rDNA alignments resulted in the loss of some resolution at the species level, but still supported the major clades with lower support and shorter distances.

Our 18S rDNA sequence data strongly support the separation of the anamixid and leucothoid clades, and grouped morphologically similar species into highly supported subclades within the genus Leucothoe. The unexpected new generic-level clade ('new' clade hereafter) groups Leucothoe toribe, L. obuchii, L. kebukai , and L. enko together. These species all have a onearticulate palp of maxilla 1 , gnathopod 1 basis widened or inflated, gnathopod 1 propodus curved or proximally inflated (not straight), and gnathopod 1 dactylus reaching less than $0.2 \times$ propodus length. Further investigation will clarify whether these 'new' clade species belong in a new genus or if they belong in the genus Paraleucothoe, whose members share the diagnostic characters listed above in addition to having moderate sexual dimorphism and an elongate maxilliped inner plate. If this clade is indeed Paraleucothoe, the diagnostic morphological characters of $\mathrm{Pa}$ raleucothoe will need to be revised. However, Leucothoe togatta White and Reimer, 2012b and L. ouraensis White and Reimer, 2012b do not share the morphological characters of this new generic level clade, suggesting that they may be placed differently in a tree containing sequences from more species; this is further supported by the relatively weak support for these species as members of the new clade $(\mathrm{ML}=89 \%, \mathrm{NJ}=$ $78 \%, \mathrm{~B}=0.92$ ) and their basal position in the grouping.

The three large subclades in the genus Leucothoe group morphologically similar species. One subclade contains Leucothoe vulgaris, L. amamiensis, L. aku$m a$ and L.akaisen, which share a rounded anterodistal head margin, gnathopod 1 dactylus reaching greater than $0.2 \times$ propodus length, and wide pereopod 5-7 bases. Additionally, these four species also all have unique color patterns. L. vulgaris has a red 'saddle', a red dot on coxa 4 , and yellow antennae; L. amamiensis has a thick pink striped pattern; L. akuma has a thin pink striped pattern; and L. akaisen has a yellow 'saddle', a red dot on coxa 4, and red striped antennae.

Another subclade contains Leucothoe elegans, $L$. hashi, L. zanpa, and L. lecroyae, and these species also share some unique morphological characters, including a thin gnathopod 1 carpus and propodus and gnathopod 1 dactylus reaching less than $0.3 \times$ propodus length. Finally, the subclade of L.trulla, L. bise, $L$. nurunuru, L. daisukei, and L. akaoni share gnathopod
1 dactylus reaching greater than $0.2 \times$ propodus length and gnathopod 2 propodus mediofacial setal row displaced to midline.

The 18S rDNA tree depicts $P$. thomasi and A. sentan as sister species and; therefore, does not support the separation of the genera Anamixis and Paranamixis. Examination of both morphological and molecular data of all species in the anamixid clade is necessary to determine the status of these genera. The connection of a $P$. thomasi anamorph and leucomorphs is also confirmed by DNA sequences with levels of divergence between 0 and 0.0175 . It is apparent that these two genera will need further future revision, but we do not formally merge them here due to lack of available data for more species from each genus. Once such data are available, we feel such a revision will be necessary.

As shown in White (2011b), molecular identification and analyses of leucothoid taxa supports traditional morphological species definitions. The available molecular data clusters morphologically similar species together, suggesting that the diagnostic morphological characters are not due to convergent adaptation to similar hosts, and do in fact reflect true evolutionary relationships between leucothoid species. However, higher level clades and relationships within Leucothoidae need to be further investigated using both morphological data and additional molecular markers to clarify species groupings within the different genera. Taxonomic revisions are not proposed here due to the lack of morphological and molecular data available for more of the 163 species in Leucothoidae. Further analyses including more species from more regions of the world will help us clarify our understanding of the evolutionary relationships within this family, and may lead to the formal taxonomic revisions that appear needed from this preliminary study.

Finally, from the phylogenetic analyses it is apparent that several closely related species inhabit different hosts, suggesting that host specificity can evolve and change rapidly in sister species. Sponge and ascidian habitation appears to have evolved more than once in the Leucothoidae, as species collected from sponges or ascidians occur in nearly every clade on the tree.

\section{Acknowledgements}

Thanks to Nathan S. White for exceptional collection assistance and to Yuka Irei for assistance with DNA extraction and amplification. Members of the University of the Ryukyus MISE Lab provided support in many forms. The Rising Star Program at the University of the Ryukyus provided laboratory space and 
logistical support. Reviews from Anne-Nina Loerz and two anonymous reviewers significantly improved the manuscript. Funding was provided by a Japanese Society for the Promotion of Science (JSPS) postdoctoral fellowship awarded to the first author (\#P10711). The second author was supported in part by the International Research Hub Project for Climate Change and Coral Reef/Island Dynamics at the University of the Ryukyus.

\section{References}

Barnard JL. 1974. Evolutionary patterns in Gammaridean Amphipoda. Crustaceana 27: 137-146.

Benson DA, Karsch-Mizrachi I, Lipman DJ, Ostell J, Wheeler D. 2005. GenBank. Nucleic Acids Research 33 (Database issue): D34-38.

Bowerbank JS. 1862. On the anatomy and physiology of the Spongiadae. Part III On the generic characters, the specific characters, and on the method of examination. Philosophical Transactions of the Royal Society 152: 1087-1135.

Campbell BC, Steffen-Campbell JD, Gill RJ. 1994.Evolutionary origin of whiteflies (Hemiptera, Sternorrhyncha, Aleyrodidae) inferred from 18S rDNA sequences. Insect Molecular Biology 3: 73-88.

Carmean D, Kimsey LS, Berbee ML. 1992. 18S rDNA sequences and the holometabolous insects. Molecular Phylogenetics and Evolution 2: 270-278.

Chalwatzis N, Hauf J, Van de Peer Y, Kinzelbach R, Zimmerman FK. 1996. 18S ribosomal RNA genes of insects - primary structure of the genes and molecular phylogeny of the holometabola. Annals of the Entomological Society of America 89: 788-803.

Crease T, Taylor D. 1998. The origin and evolution of variableregion helices in V4 and V7 of the small-subunit ribosomal RNA of Branchiopod crustaceans. Molecular Biology and Evolution 15: 1430-1446.

Dendy A. 1922. Report on the Sigmatotetraxonida collected by H.M.S. 'Sealark' in the Indian Ocean. In: Reports of the Percy Sladen Trust Expedition to the Indian Ocean in 1905, Volume 7. Transactions of the Linnean Society of London (2) 18(1): 1-164

Englisch U, Koenemann S. 2001. Preliminary phylogenetic analysis of selected subterranean amphipod crustaceans, using small subunit rDNA gene sequences. Organisms, Diversity and Evolution 1: 139-145.

Friedrich M, Tautz D. 1995. Ribosomal DNA phylogeny of the major extant arthropod classes and the evolution of myriapods. Nature 376: 165-167.

Friedrich M, Tautz D. 1997. An episodic change of rDNA nucleotide substitution rate has occurred at the time of the emergence and radiation of the insect order Diptera. Molecular Biology and Evolution 14: 644-653.

Gray JE. 1867. Notes on the arrangement of sponges, with the descriptions of some new genera. Proceedings of the Zoological Society of London, 1867 2: 492-558.

GiribetG, Carranza S, Baguna J, Riutort M, Ribera C. 1996. First molecular evidence for the existence of a Tadigrada $+\mathrm{Ar}-$ thropoda clade. Molecular Biology and Evolution 13: 76-84.

Guindon S, Gascuel O. 2003. A simple, fast, and accurate algorithm to estimate large phylogenies by maximum likelihood. Systematic Biology 52: 696-704.
Guoy M, Guindon S, Gascuel O. 2010. SeaView Version 4: A multiplatform graphical user interface for sequence alignment and phylogenetic tree building. Molecular Biology and Evolution 27: 221-224.

Hall TA. 1999. BioEdit, a user-friendly biological sequence alignment editor and analysis program for Windows 95/98/ NT. Nucleic Acids Symposium Series 41: 95-98.

Hou Z, Fu J, Li S. 2007. A molecular phylogeny of the genus Gammarus (Crustacea: Amphipoda) based on mitochondrial and nuclear gene sequences. Molecular Phylogenetics and Evolution 45: 596-611.

Hwang UW, Ree HI, Kim W. 2000. Evolution of hypervariable regions, V4 and V7, of insect 18S rRNA and their phylogenetic implications. Zoological Science 17: 111-121.

Ito A, Wada H, Aoki MN. 2008. Phylogenetic analysis of caprellid and corophioid amphipods (Crustacea) based on the $18 \mathrm{~S}$ rRNA gene, with special emphasis on the phylogenetic position of Phtisicidae. Biological Bulletin 214: 176-183.

Kim W, Abele LG. 1990. Molecular phylogeny of selected decapod crustaceans based on 18S rRNA nucleotide sequences. Journal of Crustacean Biology 10: 1-3.

Kim CB, Moon SY, Gelder SR, Kim W. 1996 Phylogenetic relationships of annelid, mollusks, \& arthropods evidenced from molecules and morphology. Journal of Molecular Evolution 43: 207-215.

Leach WE. 1814. Crustaceology. Pp. 383-437 in: Brewster D, ed., The Edinburgh Encyclopedia 7. Blackwood, Edinburgh.

Macdonald KS, Yampolsky L, Duffy JE. 2005. Molecular and morphological evolution of the amphipod radiation of Lake Baikal. Molecular Phylogenetics and Evolution 35: 323-343.

Maddison WP, Maddison DR. 2011. Mesquite, a modular system for evolutionary analysis. Version 2.75. Available from: http://mesquiteproject.org [28 Feb 2011].

Molina GI. 1782. Saggito sulla storia naturale del Chili. Bolonga: Animali del Chili.

Monniot F, Monniot C. 2001. Ascidians from the tropical western Pacific. Zoosystema 23: 201-383.

Pashley DP, MacPheron BA, Zimmer EA. 1993. Systematics of holometabolous insect orders based on 18S ribosomal RNA. Molecular Phylogenetics and Evolution 2: 132-142.

Poléjaeff N. 1883. Report on the Calcarea dredged by H.M.S. 'Challenger', during the years 1873-1876. Report on the Scientific Results of the Voyage of H.M.S. 'Challenger', 18731876. Zoology 8(2): 1-76.

Rambaut A. 2002. Sequence Alignment Editor v2.0a11. Available from: http://evolve.zoo.ox.ac.uk/.

Richards V, Thomas JD, Stanhope MJ, Shivji MS. 2007. Genetic connectivity in the Florida reef system: comparative phylogeography of commensal invertebrates with contrasting reproductive strategies. Molecular Ecology 16: 139-157.

Ronquist F, Huelsenbeck JP. 2003. MRBAYES 3, Bayesian phylogenetic inference under mixed models. Bioinformatics 19: $1572-1574$.

Saiki R, Gelfand DH, Stoffel S, Scharf SJ, Higuchi R, Horn GT, Mullis KB, Erlich HA. 1988. Primerdirected enzymatic amplification of DNA with a thermostable DNA polymerase. Science 239: 487-491.

Savigny JC. 1816. Memoires sur les Animaux sans vertebres. Permiere partie. Description et classification des animaux invertebres et articules, connus sous les noms de Crustaces, d'Insectes, d'Annelides, etc. Paris: Chez Deterville. 
Schellenberg A. 1938. Litorale Amphipoden des tropischen Pazifiks nach Sammlungen von Prof. Bock (Stockholm), Prof. Dahl (Berlin) und Prof. Pietschmann (Wein). Kungliga Svenska Vetenskapsakademiens Handlingar Series 3 16: 1-105.

Sherbakov DY, Kamaltynov RM, Ogarkov OB, Väinölä R, Vainio JK, Verheyen E. 1999. On the phylogeny of Lake Baikal amphipods in the light of mitochondrial and nuclear DNA sequence data. Crustaceana 72: 911-919.

Sinniger F, Reimer JD, Pawlowski J. 2010. The Parazoanthidae (Hexacorallia: Zoantharia) DNA taxonomy: description of two new genera. Marine Biodiversity 40: 57-70.

Sollas WJ. 1886. Preliminary account of the Tetractinellid sponges Dredged by H.M.S. 'Challenger' 1872-76. Part I. The Choristida. Scientific Proceedings of the Royal Dublin Society (new series) 5: 177-199.

Spears T, Abele LG, Kim W. 1992. The monophyly of brachyuran crabs, a phylogenetic study based on $18 \mathrm{~S}$ rRNA. Systematic Biology 41: 446-461.

Spears T, Abele LG. 2000. Branchiopod monophyly and interordinal phylogeny inferred from $18 \mathrm{~S}$ ribosomal DNA. Journal of Crustacean Biology 20: 1-24.

Spears T, DeBry RW, Abele LG, Chodyla K. 2005. Peracarid monophyly and interordinal phylogeny inferred from nuclear small-subunit DNA sequences (Crustacea, Malactostraca, Peracarida). Proceedings of the Biological Society of Washington 118: 117-157.

Soest RWM van. 1980. Marine sponges from Curaçao and other Caribbean localities. Part II. Haplosclerida. Pp. 1-173 in: Hummelinck PW, Van der Steen LJ, eds, Uitgaven van de Natuurwetenschappelijke Studiekring voor Suriname en de Nederlandse Antillen. No. 104. Studies on the Fauna of Curaçao and other Caribbean Islands 62(191).

Stebbing TRR. 1897. Amphipods from the Copenhagen Museum and Other Sources. Transactions of the Linnean Society of London, 2 Zoology 7: 25-45.

Stebbing TRR. 1899. Revision of Amphipoda (continued). Annals and Magazine of Natural History, series 74: 205-211.

Thiele J. 1903. Kieselschwämme von Ternate. II. Abhandlungen herausgegeben von der Senckenbergischen naturforschenden Gesellschaft 25: 933-968.

Thomas JD. 1997. Systematics, ecology, and phylogeny of the Anamixidae (Crustacea, Amphipoda). Records of the Australian Museum 49: 35-98.
Thomas JD, Klebba KN. 2006. Studies of commensal leucothoid amphipods, two new sponge-inhabiting species from south Florida and the western Caribbean. Journal of Crustacean Biology 26: 13-22.

Thomas JD. 2008. Commensal amphipods and host associations. Pp. 36-38 in: Hoeksema BW, van der Meij SET, eds, Cryptic marine biota of the Raja Ampat island group. Preliminary results of the Raja Ampat Expedition (2007). Naturalis, Leiden.

Thomas JD, Krapp-Schickel T. 2011. A new species of leucothoid amphipod, Anamixis bananarama, sp.n., from shallow coral reefs in French Polynesia (Crustacea, Amphipoda, Leucothoidae). Zookeys 92: 1-8.

Vosmaer GCJ. 1880. The Sponges of the Leyden Museum. 1. The family of the Desmacidinae. Notes from the Leyden Museum 2: 99-164.

White KN. 2010. Development of representative species-level molecular markers and morphological character analysis of leucothoid amphipods (Crustacea: Amphipoda). Coastal Sciences. Hattiesburg, University of Southern Mississippi. Ph.D.: 412.

White KN. 2011a. A taxonomic review of the Leucothoidae (Crustacea: Amphipoda). Zootaxa 3078: 1-113.

White KN. 2011b. Nuclear 18S rDNA as a species-level molecular marker for Leucothoidae (Amphipoda). Journal of Crustacean Biology 31: 710-716. doi: 10.1651/11-3489.1

White KN, Reimer JD. 2012a. Commensal Leucothoidae (Crustacea, Amphipoda) of the Ryukyu Archipelago, Japan. Part I: ascidian dwellers. ZooKeys 163: 13-55. doi: 10.3897/zookeys.163.2003

White KN, Reimer JD. 2012b. Commensal Leucothoidae (Crustacea, Amphipoda) of the Ryukyu Archipelago, Japan. Part II: sponge dwellers. ZooKeys 166: 1-58. doi: 10.3897/ zookeys.166.2313

White KN, Reimer JD. 2012c. Commensal Leucothoidae (Crustacea, Amphipoda) of the Ryukyu Archipelago, Japan. Part II: sponge dwellers. ZooKeys 173: 11-50. doi: 10.3897/zookeys.173.2498

Received: 19 March 2012

Revised and accepted: 12 June 2012

Published online: 4 July 2012

Editor: R. Vonk

\section{On-line supplementary material}

S1. Leucothoid specimens (from White and Reimer, 2012a, b, c) examined in this study and corresponding GenBank Accession Numbers. 


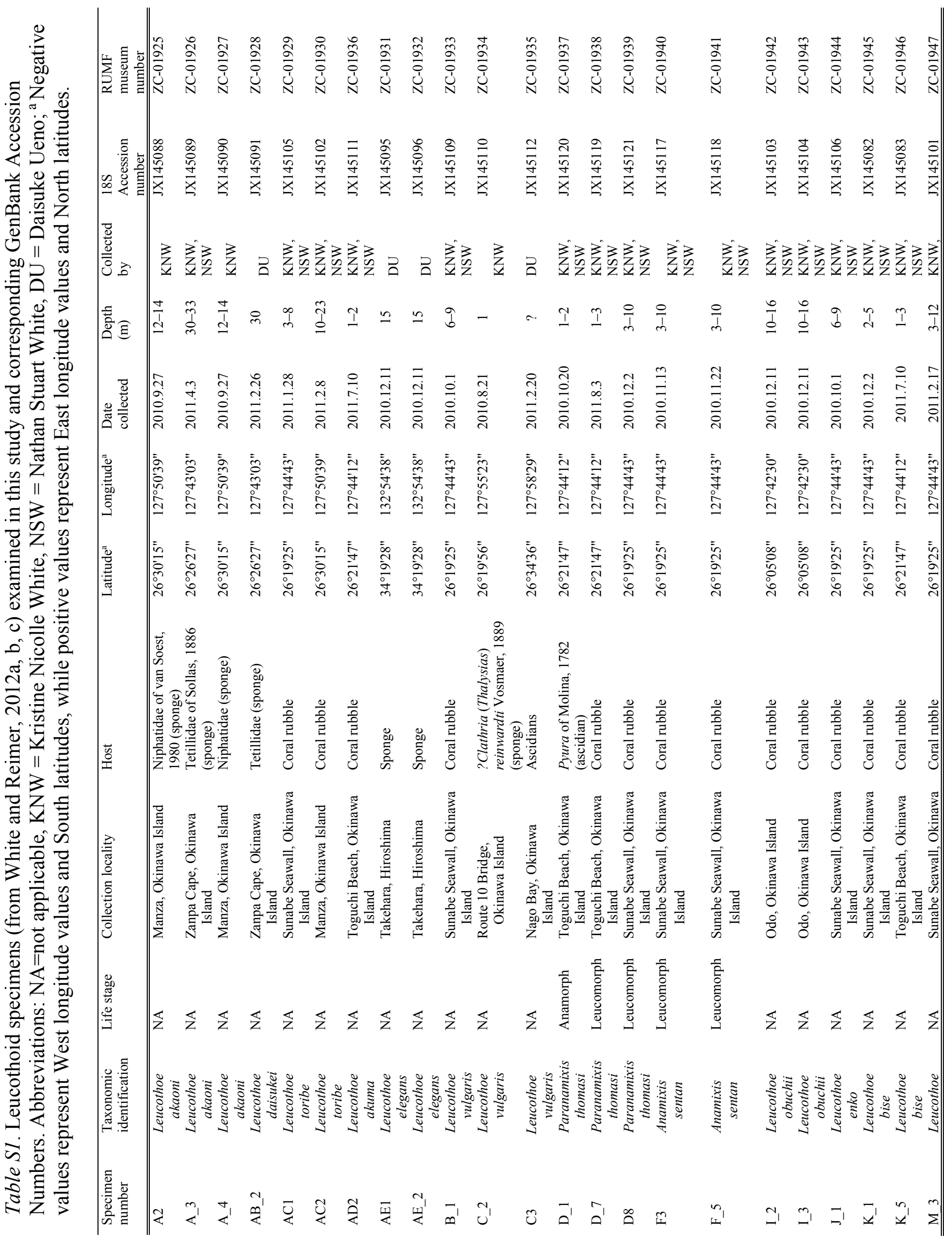




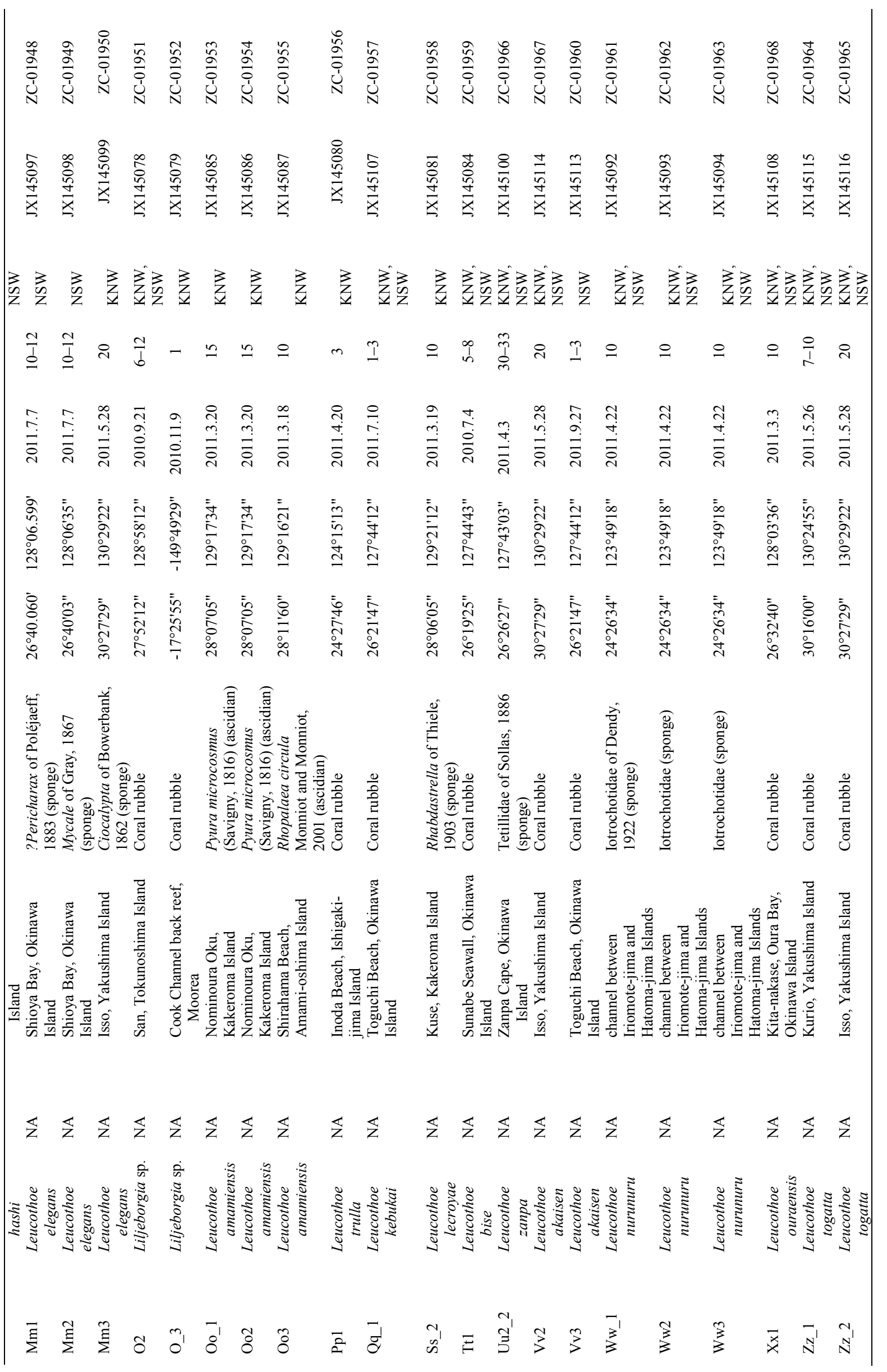

